16) R. W. Stater, J.P. Clark, A. Kitchener : Chemical factors in the flocculation of mineral slurries with polymeric flocculants, UII Intern. Miner. Process. cocess, congr., Leningrad, $\mathrm{C}-5,1$ (1968)

17) L. Usoni: Selective properties of flocculants, UII In ter. Miner, Process. Congr ., Leningrad 1968

18) O. Griot, J.A. Kitchener : Role of surface sitlanol groups in the flocculation of silica suspensions by polyac rylamide, Trans. Faraday Society, 611026 (1965)

19) H. Eyring : A theory of thixotropy, NLGI spokesman 2112 (1957)

20) H. Eyring : Flow mechanism of thixotropic substance, NLGI Spokesman 23129 (1959)

\title{
Characteristics of Solid Particles Settled in Water by Polymer-Flocculants
}

\section{- Characteristics of solid particles settled in water (4th Report) — \\ by Ryosuke HIROBE, Toshio INOUE and Tsunemasa IMAIZUMI}

Polymer-flocculants are often used in the filthy water treatment, in which suspended solid particles settle down flocculated by polymer-flocculants. This flocculation is different from coagulation by non-polymer flocculants. Polymer-flocculants are characterized by bridging particles with its polymer chains.

In the previous reports characteristics of solid particles settled with coagulation in water were studied.

In this report sedimentation characteristics of flocculated solid particles in water are studied. The form of polymer in water, the structure of sediment by polymer and the mechanical properties of sediment by polymer are discussed.

Two kinds of polyacrylamide with different molecular weight are used as nonionic polymers and polyacrylamide dissociated up to $30 \%$ is used as anionic polymer.

Non-ionic polymer chains do not change the average diameter in water solution and anionic polymer chains change the average diameter with cations in water solution or with variations of $\mathrm{pH}$. Anionic polymer is adsorbed by cations and decreases its diameter. It is dissociated in alkaline solution, so its diameter expands and reaches 2.5 times in acidic solution. This swelling coefficient can be calculated by Flory \& Fox formula.

$$
\left.[\eta]=\phi \cdot\left[\bar{\gamma}^{2}\right)^{3 / 2}\right] M=\phi \cdot\left[\alpha^{3} \cdot\left(\bar{\gamma}_{0}^{2}\right)^{3 / 2} / M\right.
$$

where $[\eta]$ is the intrinsic viscosity, $r$ is the average diameter, $r_{0}$ is the basic average diameter, $\alpha$ is the swelling coefficient, $M$ is the moleoular weight, $\phi$ is $22 \times 10^{21}$.

Bulk density of the sediment depends not only upon the bonding force determined by mutual action of Van der Waals force and electric double layer, but also the bridging effect by polymer-flocculants. Bulk density decreases in proportion to increasing bridging effect between particles and increases in proportion to decreasing bridging effect due to over-addition of polymer-flocculants.

Bridging by anionic polymer in $\mathrm{SiO}_{2}$ suspension can occur by addition of cations. $\mathrm{Na}^{1+}$ and $\mathrm{Ca}^{2+}$ ions activate $\mathrm{SiO}_{2}$ particles at high concentration and induce bridging. $\mathrm{Fe}^{3+}$ ions activate at medium concentration and can not activate at high concentration.

Mechanical properties of sediment by polymer show time-dependence. The flow curve shows not only structural viscosity but also hysteresis with bridging to prove the sediment thixotropic in nature.

\section{正誤表}

○日本鉱業会誌Vol.93, No. 1073 (昭和 52 年 7 月号) p.19 23 の論文（恒川昌美・高森隆勝・針原良治：「菱マンガン鈗一 水溶液系の界面性状と浮遊性に関する研究」) について, 誤りが ありましたので下記のように修正いたします。

\section{記}

$\mathrm{p} .21$ 第 5 図右肩に余分な文字 IEP（ $\alpha_{q}$ ) が印刷されてあ りますが図のように削除いたします。

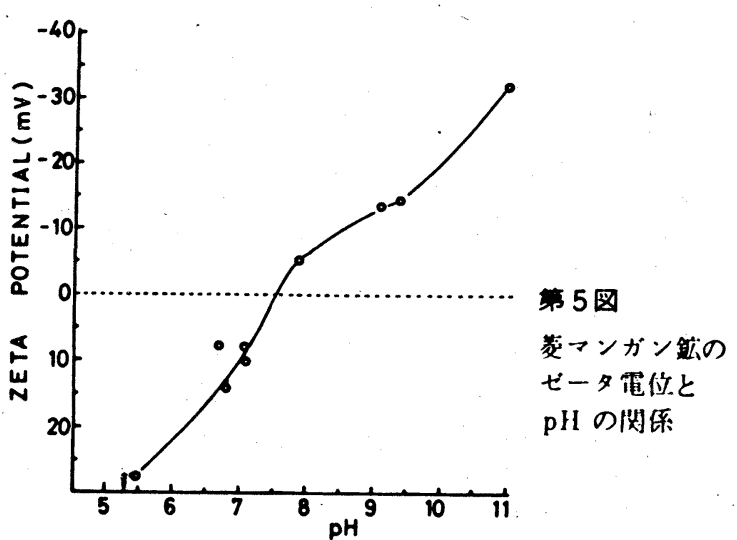

